University of Nebraska - Lincoln

DigitalCommons@University of Nebraska - Lincoln

Faculty Publications from the Harold W. Manter Laboratory of Parasitology

2012

\title{
New Species of Arostrilepis (Eucestoda: Hymenolepididae) in Members of Cricetidae and Geomyidae (Rodentia) from the Western Nearctic
}

\author{
Arseny A. Makarikov \\ Siberian Branch, Russian Academy of Sciences, makarikov@mail.ru \\ Scott Lyell Gardner \\ University of Nebraska - Lincoln, slg@unl.edu \\ Eric P. Hoberg \\ United States Department of Agriculture, ehoberg@ggpl.arsusda.gov
}

Follow this and additional works at: https://digitalcommons.unl.edu/parasitologyfacpubs

Part of the Biodiversity Commons, Parasitology Commons, Terrestrial and Aquatic Ecology Commons, and the Zoology Commons

Makarikov, Arseny A.; Gardner, Scott Lyell; and Hoberg, Eric P., "New Species of Arostrilepis (Eucestoda: Hymenolepididae) in Members of Cricetidae and Geomyidae (Rodentia) from the Western Nearctic" (2012). Faculty Publications from the Harold W. Manter Laboratory of Parasitology. 764.

https://digitalcommons.unl.edu/parasitologyfacpubs/764

This Article is brought to you for free and open access by the Parasitology, Harold W. Manter Laboratory of at DigitalCommons@University of Nebraska - Lincoln. It has been accepted for inclusion in Faculty Publications from the Harold W. Manter Laboratory of Parasitology by an authorized administrator of DigitalCommons@University of Nebraska - Lincoln. 


\title{
NEW SPECIES OF AROSTRILEPIS (EUCESTODA: HYMENOLEPIDIDAE) IN MEMBERS OF CRICETIDAE AND GEOMYIDAE (RODENTIA) FROM THE WESTERN NEARCTIC
}

\author{
Arseny A. Makarikov, Scott L. Gardner, and Eric P. Hoberg $†$ \\ Institute of Systematics and Ecology of Animals, Siberian Branch, Russian Academy of Sciences, Frunze Str. 11, 630091 Novosibirsk, Russia. \\ e-mail: makarikov@mail.ru
}

\begin{abstract}
Specimens originally identified as Arostrilepis horrida from the Nearctic are revised, contributing to the recognition of a complex of cryptic species distributed across the Holarctic region. Previously unrecognized species are described based on specimens in cricetid (Neotominae) and geomyid rodents. Arostrilepis mariettavogeae n. sp. in Peromyscus californicus from Monterey County, California and Arostrilepis schilleri n. sp. in Thomomys bulbivorus from Corvallis, Oregon are characterized. Consistent with recent studies defining diversity in the genus, form, size, and spination (pattern, shape, and size) of the cirrus are diagnostic; species are further distinguished by the relative position and length of the cirrus sac and arrangement of the testes. Species of Arostrilepis have not previously been described in rodents outside of the Arvicolinae or from localities in the Nearctic. These studies emphasize the need for routine deposition of archival specimens and information, from survey, ecological, and biogeographic studies, in museum collections to serve as self-correcting records for biodiversity at local, regional, and continental scales.
\end{abstract}

The history of Arostrilepis horrida (Linstow, 1901) (=Taenia horrida Linstow, 1901 and Hymenolepis horrida (Linstow, 1901)) is long and convoluted. Over the past century, it was generally accepted that a single species of hymenolepidid tapeworm, with an unarmed scolex lacking a vestigial rostellar apparatus, occurred in a geographically and taxonomically broad assemblage of rodents, particularly the Arvicolinae, across the Holarctic (e.g., Rausch, 1952, 1957; Schiller, 1952; Voge, 1952; Spassky, 1954; Ryzhikov et al., 1978; Fedorov, 1986). Specimens designated as A. horrida from voles and lemmings (species of Myodes Pallas, Microtus Schrank, Arvicola Lacepede, and Lemmus Link) were long considered to represent a classic, wide-spread species characterized by considerable morphological variation but without definable limits related either to geography or host association (Schiller, 1952). Further, this concept for $A$. horrida came to circumscribe many of the unarmed cestodes reported as Hymenolepis Weinland, 1858 among the Cricetidae, Dipodidae, Geomyidae, Gliridae, Heteromyidae, Muridae, Sciuridae, and Zapodidae across northern latitudes (reviewed in Makarikov et al., 2011). Although the type for A. horrida was reported to have come from Rattus norvegicus (Berkenhout) among the Muridae, this host association has remained enigmatic and is likely incorrect (Linstow, 1901; Makarikov et al., 2011; Makarikov and Kontrimavichus, 2011). Consequently, confusion over the identity, diagnostic characters, and host associations for the type, $A$. horrida (sensu stricto), has complicated the recognition of additional species in the genus (Kontrimavichus and Smirnova, 1991; Gulyaev and Chechulin, 1997; Makarikov, 2008; Haukisalmi et al., 2009; Makarikov et al., 2011).

During the early 1980s and 1990s, a view of limited diversity among these hymenolepidids began to be questioned coincidental with the description of Hymenolepis beringiensis Kontrimavichus and Smirnova, 1991 in Lemmus sibiricus Kerr from Chukhotka and the establishment of Arostrilepis Mas-Coma and Tenora, 1997 with the transfer of Hymenolepis horrida to this genus. Subsequently, Arostrilepis microtis Gulyaev and Chechulin, 1997

Received 5 August 2011; revised 16 November 2011; accepted 18 November 2011.

* Harold W. Manter Laboratory of Parasitology, University of Nebraska State Museum and School of Biological Sciences, University of Nebraska-Lincoln, Lincoln, Nebraska 68588.

$\uparrow$ United States National Parasite Collection, Animal Parasitic Disease Laboratory, USDA, Agricultural Research Service, BARC East No. 1180, 10300 Baltimore Avenue, Beltsville, Maryland 20705.

DOI: 10.1645/GE-2943.1 was discovered in root voles, Microtus oeconomus Pallas other, species of Microtus and Arvicola terrestris Linnaeus from western Siberia and the Altai Mountains (Kontrimavichus and Smirnova, 1991; Gulyaev and Chechulin, 1997; Mas Coma and Tenora, 1997). In the past decade, the recognition of a diverse assemblage of largely cryptic or poorly differentiated species within Arostrilepis has been corroborated by both morphological and molecular characters (Asakawa et al., 2002; Hoberg et al., 2003; Cook et al., 2005; Haukisalmi et al., 2009, 2010; Makarikov and Kontrimavichus, 2011; Makarikov et al., 2011). Clear limits and patterns of diversity are now apparent for 7 nominal taxa in this cryptic complex, although the number of species remaining to be discovered and characterized has yet to be completely defined (Makarikov and Kontrimavichus, 2011; Makarikov et al., 2011).

Irrespective of prior assumptions about associations among rodent hosts, all species of Arostrilepis have been described based on specimens in cricetid (Arvicolinae) rodents. It is apparent that all records of Arostrilepis and A. horrida among rodents across the Holarctic require re-evaluation based on an examination of original specimens (Makarikov et al., 2011). In the western Nearctic, tapeworms identified as A. horrida occasionally have been reported in additional hosts including Sciuridae (e.g., Tamiasciurus hudsonicus (Erxleben)), other cricetids (Neotominae, e.g., Peromyscus boylii Baird, Peromyscus californicus Gambell, Peromyscus truei Shufeldt), Heteromyidae (Perognathinae, e.g., Perognathus californicus Merriam (or Perognathus inornatus Merriam)), and Geomyidae (Thomomys bottae (Eydoux and Gervais), Thomomys bulbivorus (Richardson), Thomomys monticola J. A. Allen, Thomomys talpoides (Richardson) and Thomomys umbrinus (Richardson)) (Schiller, 1952; Voge, 1952; Howard and Childs, 1959; Frandsen and Grundmann, 1961; Gardner, 1985). Preliminary studies of this fauna of cestodes in Alaska suggest that specimens in red squirrels, Tamiasciurus hudsonicus, are attributable to a species of Arostrilepis that typically circulates in redbacked voles, Myodes rutilus (Pallas) from the taiga zone (K. G. Galbreath and E. P. Hoberg, pers. obs., and data not shown). In contrast, cestodes in cricetids, heteromyids, and geomyids appear to represent 2 independent and previously unrecognized species in their respective host groups and are the subject of the current series of descriptions; the larger assemblage of cestode species in arvicolines from Beringia and the Nearctic (Cook et al., 2005) will be addressed in a subsequent analysis (A. A. Makarikov, K. E. Galbreath, E. P. Hoberg, in preparation). 

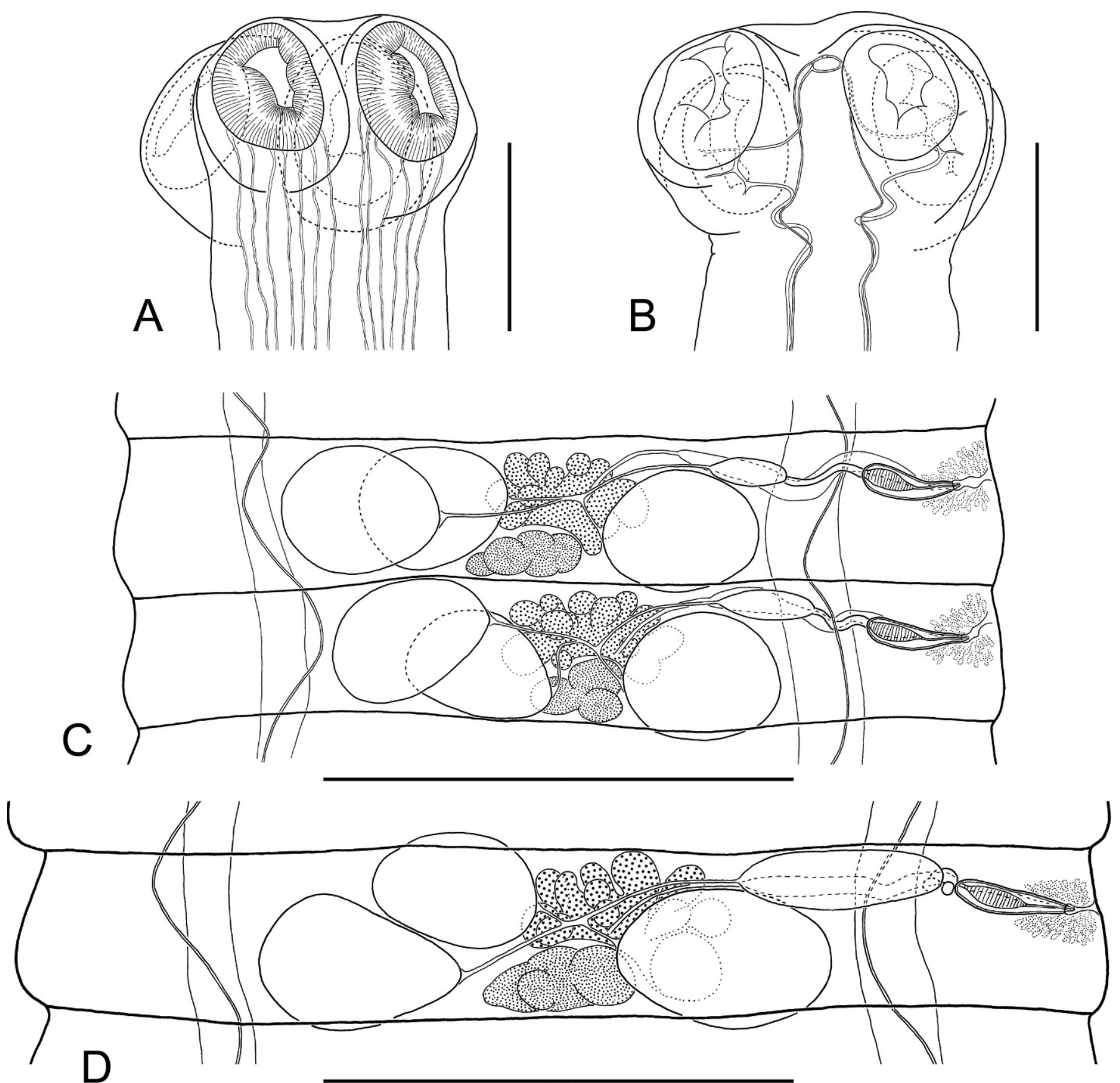

Figure 1. Arostrilepis mariettavogeae n. sp. (A) Holotype, dorsoventral view of scolex; (B) paratype (37234), dorsoventral view of scolex; (C) holotype, male mature proglottids; (D) holotype, hermaphroditic mature proglottis. Scale bars: A, B $=200 \mu \mathrm{m} ; \mathrm{C}, \mathrm{D}=500 \mu \mathrm{m}$.

Based on the studies by Voge (1952), a single species of Arostrilepis occurs in Neotominae and Perognathinae, at least in the mountainous region of the central California coast. She considered specimens in species of Peromyscus Gloger and Perognathus Wied-Neuwied collected near Monterey and Santa Cruz, California to be consistent with H. horrida (later A. horrida) and discussed the degree of variation apparent in certain morphological characters. Schiller (1952) examined some of this cestode material in a comprehensive study of variation in $H$. horrida and concluded that a single species was broadly distributed across the Holarctic in a diverse array of rodent hosts. We have had the opportunity to examine 8 of the original specimens of $H$. horrida from Peromyscus californicus collected on the Hastings Reservation near Monterey, California and deposited in the U.S. National Parasite Collection (USNPC) by Voge (1952) but not other individuals that she determined to be conspecific; these latter specimens were never deposited in any museum and are now presumed missing. We conclude that specimens from the Hastings Reservation represent an undescribed species in the A. horridacomplex, which is described herein.

Schiller (1952) concurrently provided a partial description of specimens attributed to $H$. horrida in the pocket gopher, $T$. bottae, 

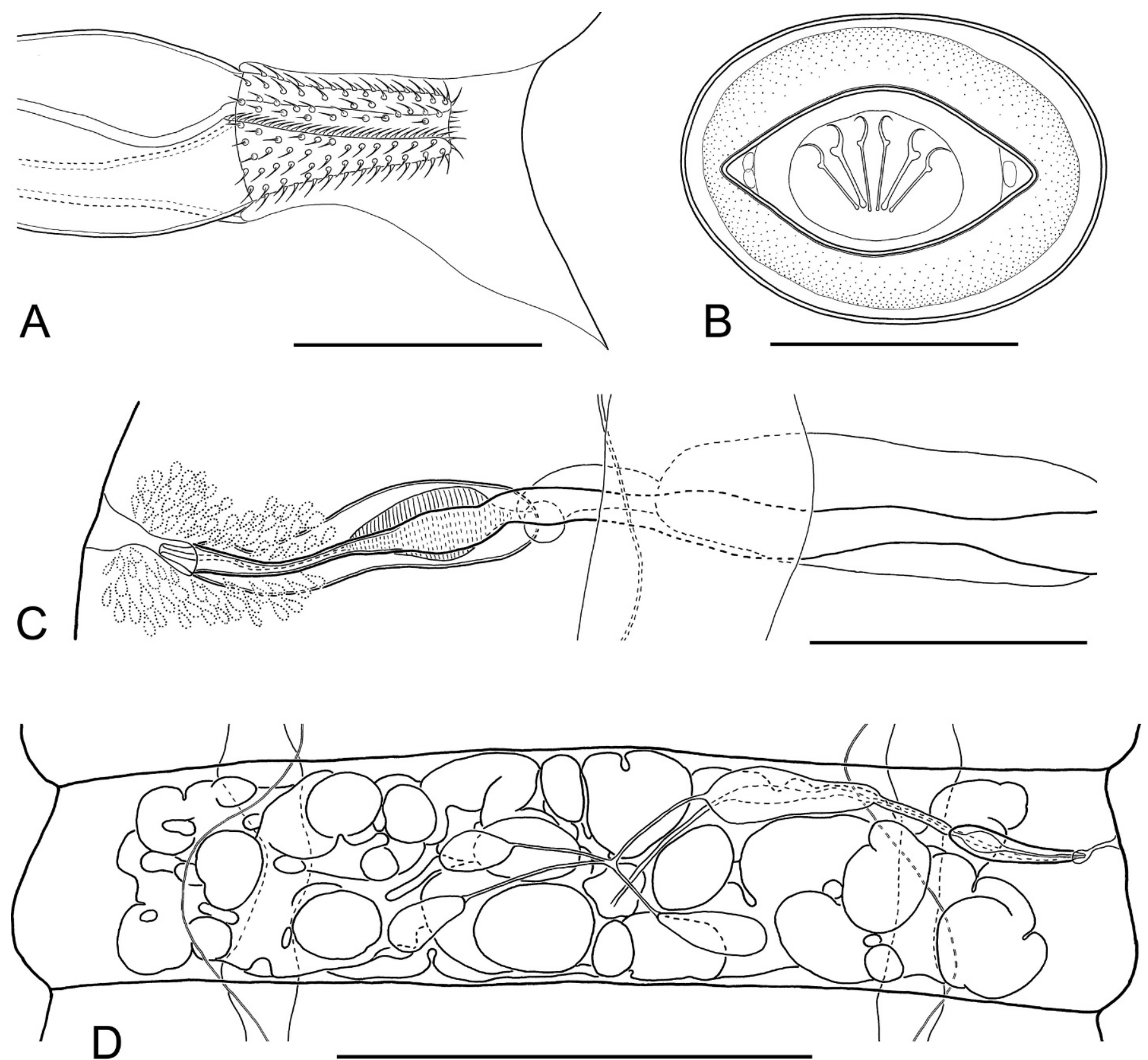

Figure 2. Arostrilepis mariettavogeae n. sp. (A) Holotype, cirrus; (B) egg (37234); (C) holotype, copulatory part of the vagina; (D) gravid proglottis (37234). Scale bars: $A, B=20 \mu \mathrm{m} ; C=100 \mu \mathrm{m} ; \mathrm{D}=500 \mu \mathrm{m}$.

from California; these specimens are also apparently missing. Additionally, specimens in other species of Thomomys WiedNeuwied from California and Utah were also not deposited in a museum repository as vouchers and are not available (Frandsen and Grundmann, 1961). Subsequently, Gardner (1985) recorded specimens apparently consistent with $H$. horrida in $T$. bulbivorus from the Willamette Valley, Oregon. Examination and comparisons of 3 specimens from the latter host, held in the Harold W. Manter Laboratory of Parasitology (HWML), revealed another undescribed species attributable to Arostrilepis. Collectively, specimens in either Neotominae or Geomyidae described herein represent the first species of Arostrilepis in hosts other than the Arvicolinae.

\section{MATERIALS AND METHODS}

Specimens of Arostrilepis described herein were derived from field collections and materials previously deposited either in the USNPC, Agricultural Research Service, USDA, Beltsville, Maryland or in the Harold W. Manter Laboratory of Parasitology (HWML), Nebraska State Museum, Lincoln, Nebraska. Voge (1952) outlined specific methods of fixation and staining for specimens originally designated as $H$. horrida in species of Peromyscus and Perognathus from the Hastings Reservation, Monterey, California; these included 8 specimens now under USNPC $37233,37234,104733$, and 104777. Gardner (1985) summarized methods of collection and specimen preparation for cestodes found in T. bulbivorus from the Willamette Valley, Oregon; these included 3 specimens with HWML collection numbers 48736, 49737, and 49738.

Specimens were studied using standard light, and differential interference contrast, microscopy. In the respective descriptions, measurements are 
TABLE I. Primary morphometric data distinguishing species of Arostrilepis (measurements in micrometers except where otherwise stated).

\begin{tabular}{lcccc}
\hline \multicolumn{1}{c}{ Characters } & Arostrilepis horrida* & Arostrilepis macrocirrosa $^{*}$ & Arostrilepis tenuicirrosa* $^{*}$ & Arostrilepis microtis $^{*}$ \\
\hline Strobila: width & $1.87-1.93 \mathrm{~mm}$ & $0.9-1.7 \mathrm{~mm}$ & $1.7-2.3 \mathrm{~mm}$ & $3.0-3.65 \mathrm{~mm}$ \\
Scolex: width & $270-300$ & $290-320$ & $280-360$ & $220-300$ \\
Suckers: size & $133-145 \times 128-134$ & $160-200 \times 140-170$ & $150-180 \times 110-140$ & $160-190 \times 120-150$ \\
Hermaphroditic mature & & & & \\
$\quad$ proglottids: size & $90-130 \times 1840-1930$ & $190-250 \times 780-1160$ & $210-270 \times 1200-1700$ & $150-270 \times 1350-2000$ \\
Testes: size & $220-290 \times 50-70$ & $110-170 \times 80-130$ & $200-300 \times 140-170$ & $160-190 \times 180-220$ \\
Cirrus sac: size & $240-270 \times 30-40$ & $195-230 \times 35-45$ & $175-225 \times 35-45$ & $220-250 \times 45-55$ \\
Cirrus: size & $88-94 \times 6-10$ & $100-128 \times 27-34$ & $64-71 \times 5-12$ & $75-85 \times 20-22$ \\
Spines: size & to 4.5 & $3.5-4$ & $2-2.5$ & $3-4$ \\
Ovary: width & $620-690$ & $250-430$ & $400-570$ & $450-620$ \\
Vitellarium: size & $35-44 \times 240-270$ & $73-86 \times 120-190$ & $80-110 \times 140-200$ & $80-110 \times 160-230$ \\
Copulative part of vagina: size & - & $100-140 \times 12-20$ & $72-83 \times 6-10$ & $100-110$ \\
Seminal receptacle: size & $250-370 \times 37-55$ & $120-190 \times 55-78$ & $175-290 \times 35-50$ & $550-840 \times 60-85$ \\
Egg: size & $30 \times 53$ & $33-45 \times 52-63$ & $30-34 \times 50-57$ & $22-25 \times 45-48$ \\
Oncosphere: size & $10 \times 13$ & $17-20 \times 25-32$ & $14-17 \times 18-22$ & $7.5-8.5 \times 14-15$ \\
Embryophore: size & $11 \times 40$ & $20-24 \times 40-45$ & $18-22 \times 35-44$ & - \\
\hline
\end{tabular}

*Measurements from Makarikov et al. (2011).

$\uparrow$ Measurements from Gulyaev and Chechulin (1997).

†Measurements from Makarikov and Kontrimavichus (2011).

given in micrometers except where otherwise stated; they are presented as the range followed by the mean and the number of the measurements $(n)$ in parentheses. Mammalian taxonomy follows Musser and Carleton (2005).

\section{RESULTS \\ DESCRIPTION \\ Arostrilepis mariettavogeae $\mathrm{n} . \mathrm{sp}$.}

(Figs. 1, 2)

Diagnosis (based on 8 specimens): Fully developed strobila 95-120 mm long, with maximum width at pregravid or gravid proglottids $1.1-1.3 \mathrm{~mm}$. Strobila flat, consisting of 600-950 craspedote proglottids. Scolex slightly compressed dorso-ventrally, 300-380 (340, $\mathrm{n}=4$ ) wide, clearly wider than neck. Suckers unarmed, ovoid in surface view, relatively small, $140-175 \times 110-125(156 \times 115, \mathrm{n}=6)$, with thick walls, prominent, usually does not reach lateral margins of scolex (Fig. 1A, B). Rhynchus and rostellar apparatus absent. Neck relatively long and narrow, 210-290 $(265, \mathrm{n}=4)$ wide.

Two pairs of osmoregulatory canals, without transverse anastomoses. Dorsal osmoregulatory canals thin, $1-3(2, \mathrm{n}=10)$ wide, situated predominantly in same sagittal plane as ventral canals. Ventral osmoregulatory canals 25-75 (48, $\mathrm{n}=10)$ wide. Position of dorsal osmoregulatory canals not always constant; their loops may be situated laterally to ventral canals. Genital pores unilateral, dextral. Genital ducts may pass dorsally or between longitudinal osmoregulatory canals within same strobila; intersegmental variation without regularity (Fig. 1C, D). Development of proglottids gradual, protandrous. Strobilar part containing juvenile proglottids without external segmentation; proglottids become externally distinct at level of premature part of strobila.

Mature proglottids $120-180 \times 985-1,130(141 \times 1,080, \mathrm{n}=10)$, transversely elongate, trapeziform (Fig. 1C, D). Testes relatively large, usually 3 in number, almost of equal size, 175-246 $\times 120-165$ $(209 \times 136, \mathrm{n}=20)$, oval or pear-shaped, commonly situated in 1 row or, rarely, testes form triangle; poral testis separated from 2 antiporal testes by female gonads. Arrangement of testes may vary. Cirrus sac relatively short, $120-145 \times 30-40(133 \times 34, \mathrm{n}=25)$, with well-developed external muscular layers. Antiporal part of cirrus sac commonly does not reach ventral longitudinal canal (Figs. 1D, 2C). Genital atrium simple, infundibular, deep, opens laterally about middle or slightly anterior of lateral proglottis margin. Cirrus small, 30-42 × 5-10 $(35 \times 7, \mathrm{n}=20)$, conical, armed along its entire length with relatively small (up to 1.5-1.8 long), needle-shaped spines (Fig. 2A). Internal seminal vesicle with circular musculature, ovoid, $55-73 \times 20-30(63 \times 25, \mathrm{n}=15)$, shorter than half of cirrus sac length (Figs. 1D, 2C). External seminal vesicle transversely elongate, $180-220 \times 47-78(198 \times 66, \mathrm{n}=10)$, clearly outlined from vas deferens, distinctly larger than seminal receptacle.

Ovary relatively small, $215-390(275, \mathrm{n}=25)$ wide, median, fanshaped, irregularly lobed, ventral to male genital organs, occupies less than half of median field of proglottid, overlapping testes (Fig. 1D). Vitellarium 40-72 × 120-166 $(58 \times 139, \mathrm{n}=15)$, postovarian, median, scarcely lobed. Vagina tubular, not clearly distinct from seminal receptacle; ventral to cirrus sac. Copulatory part of vagina $62-90 \times 6-18(76 \times 10, n=15)$, thick-walled, covered externally by dense layer of small, intensely stained cells; poral part of vagina infundibular (Fig. 2C). Conductive part of vagina 80-120 $\times 9-31(106 \times 22, \mathrm{n}=10)$, thin-walled, vastly varying in diameter depending on degree of filling with sperm. Seminal receptacle relatively small, transversely elongate; in hermaphroditic mature proglottids commonly tubular, $105-195 \times 18-33(153 \times 23, \mathrm{n}=10)$.

Uterus appears as a complex of fine-walled anastomosing tubes of varying length and diameter, positioned ventrally to other organs. With development of proglottids, tubular structures increase in width and uterus becomes labyrinthine. Uterus may pass dorsally or between longitudinal osmoregulatory canals within same strobila; intersegmental variation without regularity. Testes, cirrus sac, and vagina persist in gravid proglottids. Gravid proglottids transversely elongate, $200-312 \times 730-1,180(259 \times 935, \mathrm{n}=10)$. Fully developed uterus labyrinthine, occupying entire median field and extending bilaterally beyond longitudinal osmoregulatory canals (Fig. 2D). Uterus with numerous (up to 1,300) small eggs. Eggs 23-27 × 33-38, elliptical, with thin outer coat (up to 0.7 ); oncosphere 9-12 $\times 12-15$ (Fig. 2B). Embryophore fusiform, 10-14 $\times 23-27$, with straight polar processes. Embryonic hooks small, 7.2-8.2 long. 
TABLE I. Extended.

\begin{tabular}{|c|c|c|c|c|}
\hline Arostrilepis beringiensis: & Arostrilepis janickiił & Arostrilepis intermedia $\$$ & Arostrilepis mariettavogeae n. sp. & Arostrilepis schilleri $\mathrm{n} . \mathrm{sp}$. \\
\hline $1.4-1.6 \mathrm{~mm}$ & $1.0-2.0 \mathrm{~mm}$ & $1.35-1.8 \mathrm{~mm}$ & $1.1-1.3 \mathrm{~mm}$ & $0.9-0.98 \mathrm{~mm}$ \\
\hline $230-320$ & $190-240$ & $290-320$ & $300-380$ & $230-250$ \\
\hline $200-280 \times 750-1200$ & $90-200 \times 670-1150$ & $170-200 \times 950-1200$ & $120-180 \times 985-1130$ & $110-200 \times 440-800$ \\
\hline $100-185 \times 80-142$ & $95-175 \times 50-115$ & $145-210 \times 70-140$ & $175-246 \times 120-165$ & $110-183 \times 70-112$ \\
\hline $2.2-2.7$ & $3.5-4.3$ & $3.5-4$ & $1.5-1.8$ & $3.4-3.7$ \\
\hline $280-380$ & $230-415$ & $300-460$ & $215-390$ & $210-310$ \\
\hline $60-100 \times 130-180$ & $45-80 \times 95-185$ & $65-88 \times 130-200$ & $40-72 \times 120-166$ & $45-70 \times 80-125$ \\
\hline $55-84 \times 7-22$ & $65-85 \times 9-22$ & $84-110 \times 12-21$ & $62-90 \times 6-18$ & $61-77 \times 10-15$ \\
\hline $100-180 \times 30-40$ & $87-162 \times 47-70$ & $110-175 \times 35-65$ & $105-195 \times 18-33$ & $75-105 \times 25-42$ \\
\hline $30-36 \times 48-56$ & $27-36 \times 43-52$ & $36-42 \times 60-65$ & $23-27 \times 33-38$ & $24-31 \times 40-48$ \\
\hline
\end{tabular}

\section{Taxonomic summary}

Type host: Peromyscus californicus (Gambel, 1848) (Rodentia: Cricetidae: Neotominae).

Other potential hosts: Based on Voge (1952), conspecific tapeworms were reported in Peromyscus truei (Shufeldt, 1885), Peromyscus boylii (Baird, 1855), and P. inornatus Merriam, 1889 (originally reported as Perognathus californicus Merriam; Heteromyidae: Perognathinae) at type locality.

Type locality: Hastings Reservation, Monterey County, California; ca. $36^{\circ} 12^{\prime} 30^{\prime \prime} \mathrm{N}, 121^{\circ} 33^{\prime} 30^{\prime \prime} \mathrm{W}$. Collected by M. Voge between 5 March and 15 June 1945.

Other localities: Based on Voge (1952), Swanton, Santa Cruz County, California; ca. $37^{\circ} 03^{\prime} 05^{\prime \prime} \mathrm{N}, 122^{\circ} 13^{\prime} 35^{\prime \prime} \mathrm{W}$, in P. californicus.

Type material: Holotype USNPC 104733 ex P. californicus (male host, field number SV-540). Paratypes, include 5 specimens under USNPC 37234 ex P. californicus (SV-540). Vouchers include 2 specimens, USNPC 104777 in type host from type locality (SV-540) and USNPC 37233 in P. californicus (female host, field number SV-109) from type locality. All specimens are deposited in the U.S. National Parasite Collection, Beltsville, Maryland.

Etymology: Arostrilepis mariettavogeae n. sp. is named in honor of Dr. Marietta Voge for seminal morphological studies among the unarmed hymenolepidids of rodents.

\section{Remarks}

Arostrilepis mariettavogeae n. sp. is distinguished from 7 recognized congeners based on an exceptionally small conical cirrus armed with miniscule, needle-shaped spines. In specimens of A. microtis and Arostrilepis tenuicirrosa Makarikov, Gulyaev and Kontrimavichus, 2011, the cirrus is conical basally but terminates distally in a narrow cylindrical extension; in Arostrilepis macrocirrosa Makarikov, Gulyaev and Kontrimavichus, 2011, the cirrus is conical and massive. In contrast, the cirrus in all other species, Arostrilepis beringiensis, Arostrilepis intermedia Makarikov and Kontrimavichus, 2011, and Arostrilepis janickii Makarikov and Kontrimavichus, 2011 is cylindrical throughout. The form of the cirrus in $A$. horrida was unknown until recently
(Makarikov et al., 2011). In specimens of $A$. horrida the cirrus is cylindrical, substantially longer than that in A. mariettavogeae, and is armed with relatively large rosethorn-shaped spines. As has been established, the cirrus and its spination are diagnostic among all recognized species of Arostrilepis (Makarikov and Kontrimavichus, 2011; Makarikov et al., 2011).

Additional characters, based on comparisons of strobila and segments in similar stages of development, also contribute in distinguishing among the species. Although there is variation in the structure of the unarmed holdfast among these species, in $A$. mariettavogeae the suckers usually do not reach the lateral margins of scolex. In hermaphroditic mature proglottids, the antiporal part of the cirrus sac commonly does not reach the ventral longitudinal canal and the tubular seminal receptacle is smaller than the external seminal vesicle. The cirrus sac in specimens of $A$. mariettavogeae is shorter than that in all other species of Arostrilepis except A. beringiensis (see Table I). Gravid proglottids are transversely elongate and the polar processes of the embryophore are straight.

Further comparisons serve to highlight the distinct nature of $A$. mariettavogeae among the 7 species. Specimens of $A$. mariettavogeae are distinguished from $A$. horrida, A. tenuicirrosa, $A$. intermedia, and $A$. macrocirrosa as the testes are situated in 1 row; in the latter species, the testes are arranged in a triangle. The scolex and the testes are large relative to those in A. janickii (see Table I). The ovary is smaller relative to those in A. horrida, A. microtis, and A. tenuicirrosa (see Table I). The seminal receptacle is smaller than in $A$. horrida and A. microtis. The eggs are smaller than in $A$. horrida, A. macrocirrosa, A. tenuicirrosa, A. beringiensis, A. intermedia, and A. janickii.

\section{Arostrilepis schilleri n. sp.} (Figs. 3, 4)

Diagnosis (based on 3 specimens): Fully developed strobila, $67 \mathrm{~mm}$ long, with maximum width at pregravid or gravid proglottids, $0.9-0.98 \mathrm{~mm}$. Strobila flat, consisting of about 560 craspedote proglottids. Scolex slightly compressed dorso-ventral1y, 230-250 (240, n = 2) wide, clearly wider than neck. Suckers unarmed, ovoid in surface view, 140-176 × 115-140 $(160 \times 130$, n 

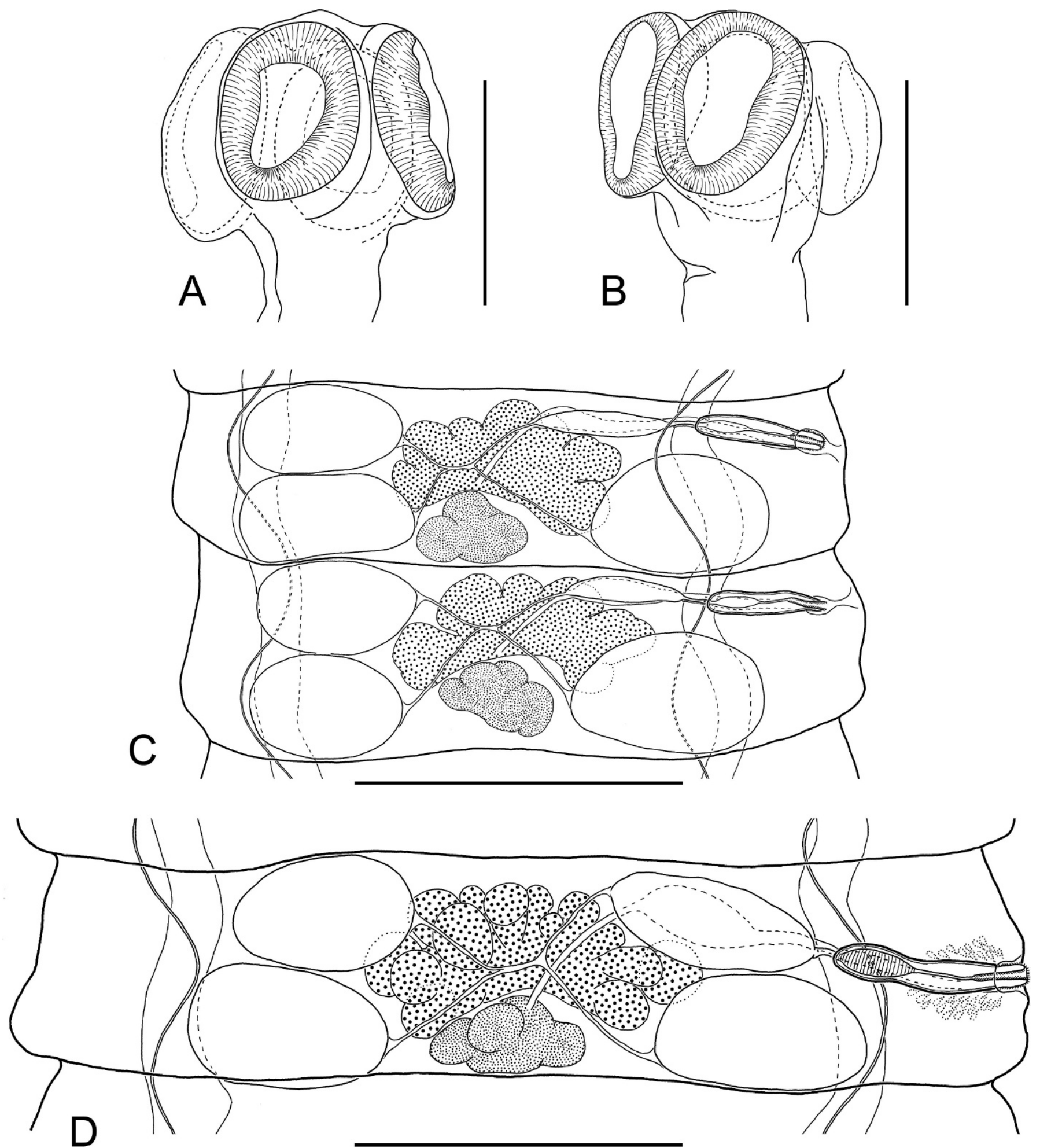

Figure 3. Arostrilepis schilleri n. sp. (A) Paratype (49738), sublateral view of scolex; (B) paratype (49737), sublateral view of scolex; (C) holotype, male mature proglottids; (D) holotype, hermaphroditic mature proglottis. Scale bars: A, B = $200 \mu \mathrm{m}$; C, D $=250 \mu \mathrm{m}$.

=7), prominent, with thick walls (Fig. 3A, B). Rhynchus and rostellar apparatus absent. Neck relatively long and narrow, 105$120(115, \mathrm{n}=5)$ wide.

Two pairs of osmoregulatory canals, without transverse anastomoses. Dorsal osmoregulatory canals thin, $1-3(1.8, \mathrm{n}=7)$ wide, situated predominantly in same sagittal plane as ventral canals. Ventral osmoregulatory canals 28-67 $(45, \mathrm{n}=7)$ wide. Position of dorsal osmoregulatory canals not always constant; their loops may be situated laterally to ventral canals. Genital pores unilateral, dextral. Genital ducts may pass dorsally or between 

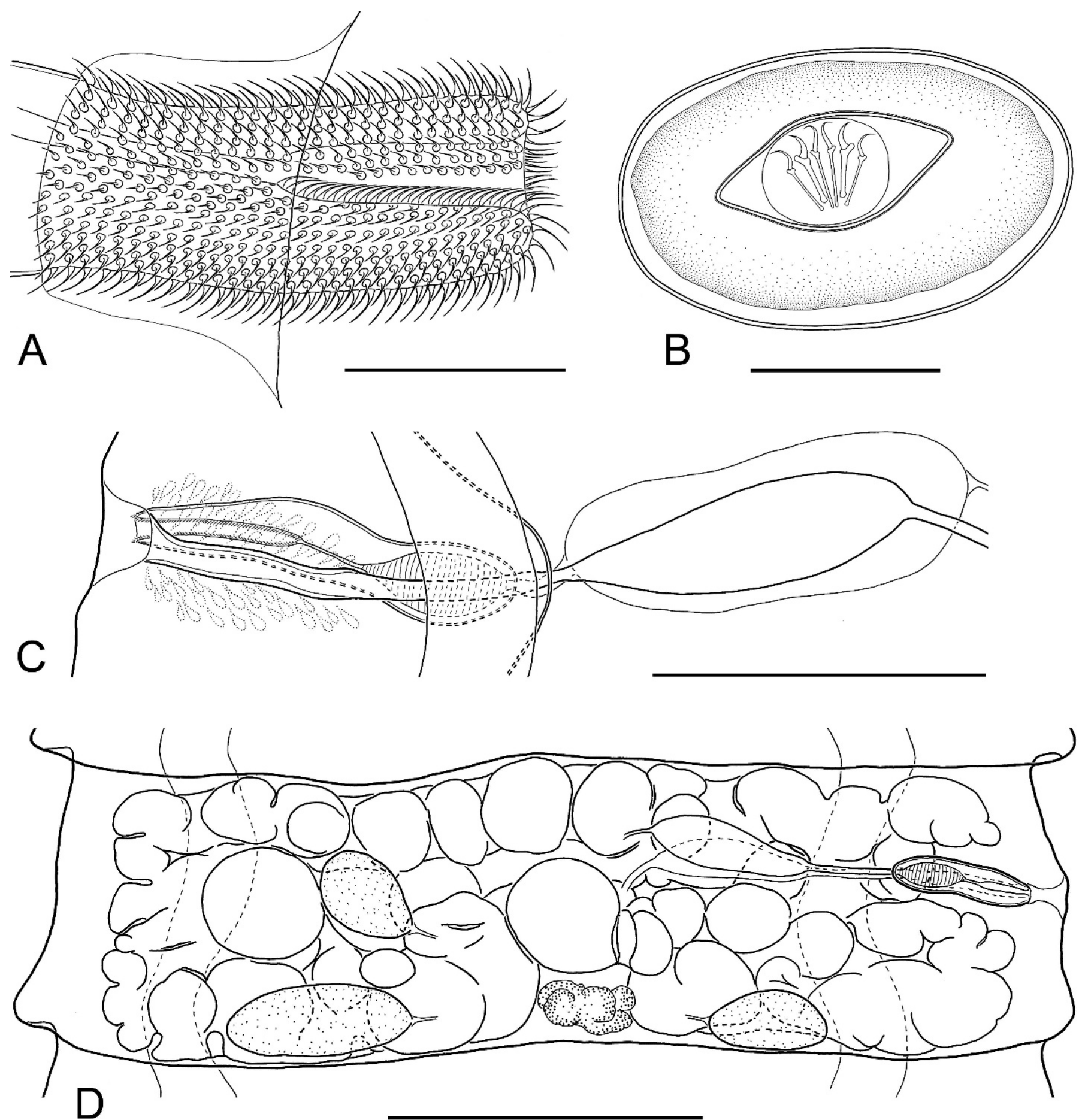

Figure 4. Arostrilepis schilleri n. sp. (A) Paratype (49737), cirrus; (B) holotype, egg; (C) holotype, copulatory part of the vagina; (D) holotype, gravid proglottis. Scale bars: A, B $=20 \mu \mathrm{m} ; \mathrm{C}=100 \mu \mathrm{m} ; \mathrm{D}=250 \mu \mathrm{m}$.

longitudinal osmoregulatory canals within same strobila; intersegmental variation without regularity (Fig. 3C). Development of proglottids gradual, protandrous. Strobilar part containing juvenile proglottids without external segmentation; proglottids become externally distinct at level of premature part of strobila.

Mature proglottids $110-200 \times 440-800(157 \times 643, \mathrm{n}=14)$, transversely elongate, trapeziform (Fig. 3C, D). Testes relatively large, usually 3 in number, almost of equal size, $110-183 \times 70$
$112(145 \times 87, \mathrm{n}=21)$, pear-shaped or oval, commonly situated in triangle; poral testis separated from 2 antiporal testes by female gonads. Arrangement of testes may vary. Cirrus sac relatively short, $95-123 \times 22-31(109 \times 25, \mathrm{n}=17)$, with well-developed external muscular layers. Antiporal part of cirrus sac reaching ventral longitudinal canal, rarely overlapping or slightly crossing it (Figs. 3D, 4C). Genital atrium simple, cup-shaped, deep, opens laterally about middle of lateral proglottid margin. Cirrus small, 
61-74 × 17-21 $(67 \times 18, \mathrm{n}=16)$, cylindrical, armed along its entire length (up to 3.4-3.7 long) with rosethorn-shaped spines (Fig. 4A). Internal seminal vesicle with circular musculature, ovoid, 43-57 $\times 17-26(49 \times 20, \mathrm{n}=7)$, shorter than half of cirrus sac length (Figs. 3D, 4C). External seminal vesicle transversely elongate, $90-190 \times 45-85(137 \times 61, \mathrm{n}=8)$, clearly outlined from vas deferens, distinctly larger than seminal receptacle.

Ovary 210-310 (251, $\mathrm{n}=13)$ wide, median, fan-shaped, irregularly lobed, ventral to male genital organs, occupying substantial part of median field, overlapping testes (Fig. 3D). Vitellarium $45-70 \times 80-125(61 \times 110, \mathrm{n}=12)$, postovarian, median, scarcely lobed. Vagina tubular, clearly distinct from seminal receptacle; ventral to cirrus sac. Copulatory part of vagina $61-77 \times 10-15(69 \times 12, \mathrm{n}=8)$, thick-walled, covered externally by dense layer of small intensely stained cells; poral part of vagina infundibular (Fig. 4C). Conductive part of vagina $85-117 \times 8-20$ $(98 \times 8-13)$, thin-walled, vastly varying in diameter depending on degree of filling with sperm. Seminal receptacle relatively small, transversely elongate, $75-105 \times 25-42(88 \times 30, \mathrm{n}=8)$.

Uterus appears as a complex of fine-walled anastomosing tubes of varying length and diameter, positioned ventrally to other organs. With development of proglottids, tubular structures increase in width and uterus becomes labyrinthine. Testes, cirrus sac, and vagina remain in fully gravid proglottids. Gravid proglottids transversely elongate, 230-295 × 870-980 $(258 \times$ $938, \mathrm{n}=5$ ). Fully developed uterus labyrinthine, occupying entire median field and extending bilaterally beyond longitudinal osmoregulatory canals (Fig. 4D). Uterus with numerous (up to 800) small eggs. Eggs $24-31 \times 40-48$, elliptical, with thin outer coat (up to 0.6); oncosphere 9-13 $\times 10-15$ (Fig. 4B). Embryophore fusiform, 12-16 $\times$ 23-31, with straight polar processes. Embryonic hooks small, 7.7-9 long.

\section{Taxonomic summary}

Type host: Thomomys bulbivorus (Richardson) (Rodentia: Geomyidae).

Symbiotype: Museum of Southwestern Biology, Mammal Collection No. 89020 (field collection SLG-8-81), skull only.

Type locality: Adjacent to Corvallis, Oregon, in the middle Willamette Valley; ca. $123^{\circ} 16^{\prime} 36^{\prime \prime} \mathrm{N}, 44^{\circ} 32^{\prime} 54^{\prime \prime} \mathrm{W}$; collected by S. L. Gardner on 8 September 1981.

Type material: Holotype, single slide, Harold W. Manter Laboratory (HWML 48736) in type host and locality (Field Collection No. SLG-8-81 [62] Slide A 49). Paratypes, 2 specimens on separate slides from type host and locality, HWML 49737 (SLG-8-81 [62] Slide A21) and HWML 49738 (SLG-8-81 [62] Slide A 22). All the type materials are deposited in the HWML at the University of Nebraska, Lincoln, Nebraska.

Etymology: Arostrilepis schilleri n. sp. is established in honor of Dr. Everett L. Schiller in recognition of critical studies on hymenolepidid cestodes of rodents.

\section{Remarks}

Arostrilepis schilleri n. sp. is distinguished from $A$. horrida, $A$. microtis, $A$. beringiensis, A. macrocirrosa, A. tenuicirrosa, $A$. intermedia, A. janickii, and A. mariettavogeae by the length and shape of the cirrus. In specimens of $A$. schilleri, the cirrus is longer relative to those in $A$. beringiensis and $A$. mariettavogeae but smaller in comparison to A. horrida, A. microtis, A. macrocirrosa, and A. intermedia (see Table I). The cirrus is armed with relatively large, rosethorn-shaped spines and has a cylindrical form; these features distinguish $A$. schilleri from $A$. macrocirrosa (massive conical cirrus), $A$. microtis (cirrus with wide conical basal region and a cylindrical distal region), A. tenuicirrosa (cirrus is armed with relatively small, needle-shaped spines and has conical basal region and a very narrow cylindrical distal region), and $A$. mariettavogeae (minute conical cirrus is armed with miniscule, needle-shaped spines). In A. schilleri, the form and the length of the cirrus is similar to A. janickii but, in the former species, the width is considerably greater. Specimens of $A$. schilleri are further distinguished from congeners based on the exceptionally short cirrus sac, which also attains but rarely overlaps the ventral longitudinal excretory canal. The strobila is narrower relative to those in $A$. horrida, A. tenuicirrosa, A. microtis, A. beringiensis, and $A$. intermedia. The ovary is smaller than in $A$. horrida, A. tenuicirrosa, and A. microtis. The embryophore is smaller relative to those in $A$. horrida, A. macrocirrosa, A. tenuicirrosa, and A. janickii (see Table I). Arostrilepis schilleri is also distinguished from $A$. janickii and $A$. beringiensis as its testes are arranged in a triangle; in the 2 latter species, the testes form a flat angle or are situated in 1 row. Similarly, the testes form 1 row in A. microtis and A. mariettavogeae. Furthermore, the gravid proglottids are transversely elongate, external seminal vesicle distinctly larger than seminal receptacle, and the polar processes of the embryophore are straight in A. schilleri.

\section{DISCUSSION}

The current study provides additional confirmation of a large complex of previously unrecognized species in the genus Arostrilepis. The limits for this assemblage of species remain to be defined. We describe $A$. mariettavogeae $\mathrm{n}$. $\mathrm{sp}$. based on specimens of hymenolepidids in rodents (Cricetidae [Neotominae] and Heteromyidae [Perognathinae]) originally collected and examined by Voge (1952) from 2 localities along the central California coast. Further, we describe A. schilleri n. sp. for specimens in Geomyidae from the central Willamette Valley of Oregon (Gardner, 1985). Species of Arostrilepis have not previously been described in rodents other than those among the Arvicolinae or from localities in the Nearctic.

Specimens of $A$. mariettavogeae (parasites designated as $H$. horrida by Voge [1952]) were most commonly found infecting Peromyscus californicus; maximum intensity reported was 122 cestodes in a female host collected at the type locality on 21 March 1945. Other species of Peromyscus at the Hastings Reservation harbored fewer parasites (A. mariettavogeae was not found in $P$. maniculatus [Wagner]) and only 1 of $40 P$. inornatus, a heteromyid rodent in the Perognathinae, was infected. Specimens identified as A. mariettavogeae were also reported by Voge (1952) in $P$. californicus at another locality from the foothills adjacent to the Pacific coast. These observations suggest that deer mice, members of the Neotominae, are typical hosts for this species of Arostrilepis, although detailed and comprehensive surveys among sympatric arvicolines have not been conducted across California.

Voge (1952) concluded that a single species was present in circulation among these rodent hosts along the central coastal region of California. Conspecificity of the Arostrilepis in this sympatric assemblage, involving 3 species of Peromyscus and a single Perognathus, cannot be immediately assumed. The detailed descriptions developed by Voge (1952) do not provide a basis for 
definitive determination about the status of these populations of cestodes; numerous specimens from other than P. californicus were not retained in museum collections. Current evidence does not either refute, or corroborate, the occurrence of a single species in Neotominae and Perognathinae. For example, in species of Myodes from some localities across the Holarctic, there may be 5 species of sympatric Arostrilepis, and multiple species infections are known to occur in some hosts (Haukisalmi et al., 2009; A. Makarikov, unpubl. obs.). New collections in central California, and more broadly across the boreal zone of North America, accompanied by integrated morphological and molecular sampling are necessary to completely understand the diversity of these cestodes.

Although Geomyidae and species of Thomomys have been reported as hosts for $A$. horrida, none of these records, beyond Oregon, can be substantiated (Schiller, 1952; Voge, 1952; Howard and Childs, 1959; Frandsen and Grundmann, 1961). Further, conspecificity of cestodes in Thomomys spp. cannot now be determined based on the partial descriptions provided by Schiller (1952); spination of the cirrus may be similar to that described in A. schilleri, but specific details of the arrangement and relative dimensions of the testes and other genital organs are insufficient to unequivocally establish identity for cestodes in T. bulbivorus and $T$. bottae. The distribution of Arostrilepis specimens in Thomomys suggests the occurrence of a widespread species in these hosts or, alternatively, a geographically broad series of discrete and isolated species in western North America.

Nearly all recognized and described species of Arostrilepis (7 of 9) have been found in rodents of the Arvicolinae across the Holarctic (e.g., Makarikov, 2008; Makarikov and Kontrimavichus, 2011; Makarikov et al., 2011). Preliminary phylogenetic assessments of this fauna suggest an extended association with Arvicolinae, first in Eurasia and secondarily in the Nearctic, established by biotic expansion from east to west across Beringia during the Pliocene and Pleistocene (e.g., Cook et al., 2005; K. E. Galbreath and E. P. Hoberg, unpubl. obs.). This may be consistent with origins of $A$. mariettavogeae and A. schilleri in their respective hosts linked to colonization from arvicolines and diversification in the Nearctic; an attendant assumption is that both species have been found in their typical hosts. Such a hypothesis can be evaluated by making new field-collections, followed by subsequent phylogenetic analysis, that will enable researchers to explore the extent of host and geographic associations in the Nearctic. Interestingly, Geomyidae are an endemic group of rodents in the Nearctic, with a fossil history extending from at least early Miocene time and coinciding with a broad transcontinental distribution (Kurtén and Anderson, 1980). If the age of association of these cestodes with geomyids is considerable, we might also predict that the fauna has diversified through regional, to local, isolation across the Nearctic, perhaps in a similar manner as exemplified by the helminth faunas of pikas, i.e., species of Ochotona Link, Lagomorpha (DuretteDesset et al., 2010; Galbreath and Hoberg, 2012). In parallel to the history proposed for Arostrilepis in geomyids, host colonization from arvicolines to pocket gophers was postulated as the mechanism to account for the diversity and distribution of some species of Microcephaloides Haukisalmi, Hardman, Hardman, Rausch and Hentonnen, 2008 and Anoplocephaloides Baer, 1927 in the Nearctic (Haukisalmi et al., 2008).

All records for non-arvicoline hosts require confirmation based on examination of original specimens. The process is complicated by the fact that few, if any, specimens have been retained in museum repositories. Thus, we suggest that the records, particularly of $A$. horrida in such families as Cricetidae (non-arvicolines), Dipodidae, Geomyidae, Gliridae, Heteromyidae, Muridae, Sciuridae, and Zapodidae could represent: (1) misidentifications of other hymenolepidids; (2) misidentifications of other Arostrilepis species; or (3) less often, potentially undescribed species. That we have discovered previously unrecognized species of Arostrilepis in Geomyidae, Heteromyidae, and non-arvicoline Cricetidae suggests that the possibility of broader diversity beyond arvicoline hosts cannot be disregarded. A review of specimens and records where available, however, has supported the view of Arvicolinae as primary hosts for species of Arostrilepis (Makarikov, 2008; Makarikov and Kontrimavichus, 2011; Makarikov et al., 2011).

Erroneous records for the patterns and distribution of diversity confound our understanding of the biosphere (e.g., Brooks and Hoberg, 2006). Museum collections and archives are at the foundations for understanding biotic structure, and specimens represent the self-correcting records for biodiversity that define the distribution of species and associations within landscapes, ecosystems, and communities. Self-correcting records of biodiversity are only effective when specimens and information are archived, thus making them available and amenable to review and application of new approaches to explore diversity (Hoberg, 2002; Cook et al., 2005; Hoberg et al., 2009). Although we cannot correct prior practices related to deposition of specimens, future researchers involved in survey and inventory, or in ecological and biogeographic-phylogeographic investigations should be not only encouraged, but required, to archive specimens as an adequate representation of faunal diversity at local, regional, and continental scales.

\section{ACKNOWLEDGMENTS}

We thank Patricia Pilitt, Associate Curator of the U.S. National Parasite Collection, for assistance in assembling cestode specimens for the current study. We also thank Joseph Cook, Curator of Mammals at the Museum of Southwestern Biology (MSB), University of New Mexico for access to comparative specimens and collection records for mammalian hosts. Research by A.A.M. was supported by a postdoctoral fellowship from the European Union Structural Funds Project "Postdoctoral Fellowship Implementation in Lithuania" within the framework of the Measure for Enhancing Mobility of Scholars and Other Researchers and the Promotion of Student Research (VP1-3.1-ŠMM-01) under the Program of Human Resources Development Action Plan. Further support for A.A.M. was provided in part by the National Science Foundation (PBI grants DEB 0818696 and 0818823 ) coordinated by J. Caira, University of Connecticut. Support for A.A.M. during his visit to the Harold W. Manter Laboratory was funded by the Manter Laboratory Endowment Fund and NSF grant DBI-0646356. This study is a contribution of the Beringian Coevolution Project, supported in part by the National Science Foundation (DEB 0196095 and 0415668) and organized by Joseph Cook at the MSB and E.P.H. at the USNPC, to explore the structure and distribution of complex host-parasite systems across the Holarctic.

\section{LITERATURE CITED}

Asakawa, M., F. Tenora, And B. Koubkova. 2002. Arostrilepis horrida (Linstow, 1901) (Cestoda: Hymenolepididae) from Eothenomys spp. (Rodentia) in Japan. Biogeography 4: 51-55.

Brooks, D. R., AND E. P. Hoberg. 2006. Systematics and emerging infectious diseases: From management to solution. Journal of Parasitology 92: 426-429.

Cook, J. A., E. P. Hoberg, A. Koehler, H. Henttonen, L. Wickström, V. Haukisalmi, K. Galbreath, F. Chernyavski, N. Dokuchaev, A. LAHZUHTKIN ET AL. 2005. Beringia: Intercontinental exchange and diversification of high latitude mammals and their parasites during the Pliocene and Quaternary. Mammal Study 30: S33-S44. 
Durette-Desset, M.-C., K. E. Galbreath, and E. P. Hoberg. 2010. Discovery of new Ohbayashinema spp. (Heligmosomidae: Nematoda) in Ochotona princeps and $O$. cansus (Lagomorpha: Ochotonidae) from western North America and central Asia, with consideration of historical biogeography. Journal of Parasitology 96: 569-579.

Fedorov, K. P. 1986. Patterns of spatial distribution of parasitic worms. Izdatel'stvo Nauka, Novosibirsk, Russia, $256 \mathrm{p}$.

Frandsen, J. C., and A. W. Grundmann. 1961. Endoparasitism in isolated populations of rodents of the Lake Bonneville Basin, Utah. Journal of Parasitology 47: 391-396.

Galbreath, K. E., and E. P. Hoberg. 2012. Return to Beringia: Parasites reveal cryptic biogeographic history of North American pikas. Proceedings of the Royal Society, B. 279: 371-378.

GARDNER, S. L. 1985. Helminth parasites of Thomomys bulbivorus (Richardson) (Rodentia; Geomyidae), with the description of a new species of Hymenolepis (Cestoda). Canadian Journal of Zoology 63: $1463-1469$.

Gulyaev, V. D., And A. I. Chechulin. 1997: Arostrilepis microtis n. sp. (Cyclophyllidea: Hymenolepididae), a new cestode species from Siberian rodents. Research and Reviews in Parasitology 57: 103-107.

Haukisalmi, V., L. M. Hardman, P. Foronda, C. Feliu, J. Laakkonen, J. NiemimaA, J. T. Lehtonen, and H. Henttonen. 2010. Systematic relationships of hymenolepidid cestodes of rodents and shrews inferred from sequences of $28 \mathrm{~S}$ ribosomal RNA. Zoologica Scripta 39: 631-641.

M. Hardman, R. L. Rausch, and H. HentTonen. 2008. Molecular systematic of the Holarctic Anoplocephaloides variabilis (Douthitt, 1915) complex, with the proposal of Microcephaloides n. g. (Cestoda: Anoplocephalidae). Systematic Parasitology 70: 15-26.

, H. Henttonen, L. M. Hardman, M. Hardman, J. Laakkonen, G. Muraveva, J. Neimimaa, S. Shulunov, and O. Vapalahu. 2009. Review of tapeworms of rodents in the Republic of Buryatia, with emphasis on anoplocephalid cestodes. ZooKeys 8: 1-18.

Hoberg, E. P. 2002. Foundations for an integrative parasitology: Collections archives and biodiversity informatics. Comparative Parasitology 69: 124-131.

, S. J. Kutz, K. E. Galbreath, and J. Cook. 2003. Arctic biodiversity: From discovery to faunal baselines-Revealing the history of a dynamic ecosystem. Journal of Parasitology 89: S84-S95.

, P. A. Pilitt, and K. E. Galbreath. 2009. Why museums matter: A tale of pinworms (Oxyuroidea: Heteroxynematidae) among pikas (Ochotona princeps and O. collaris) in the American West. Journal of Parasitology 95: 490-501.

Howard, W. E., AND H. E. ChILds. 1959. Ecology of pocket gophers with emphasis on Thomomys bottae mewa. Hilgardia 29: 277-358.

Kontrimavichus, V. L., and L. V. Smirnova. 1991. Hymenolepis beringiensis sp. $\mathrm{n}$. from the Siberian lemming (Lemmus sibiricus Kerr) and the problem of the sibling species in helminthology. In
Evoljucia parazitov, Materialy I Vsesojuznogo simpoziuma, G. P. Krasnosohekov, V. A. Roitman, M. D. Sonin, and L. V. Chesnova (eds.). Tol'yatti, Akademiya Nauk SSSR, p. 90-104.

Kurtén, B., and E. Anderson. 1980. Pleistocene mammals of North America. Columbia University Press, New York, New York, 442 p.

Linstow, O. 1901. Taenia horrida, Tetrabothrium macrocephalum, un Heterakis distans. Archiv für Naturgeschichte, Berlin 67: 1-10.

Makarikov, A. A. 2008. Cestodes of the family Hymenolepididae Perrier, 1897 in rodents from the Asian part of Russia. Dissertatsija Kandidata Biologicheskikh Nauk, Rossiiskaja Akademija Nauk Sibirskoe Otdelenie Institut Sistematiki I Ekologii Zhivotnikh, Novosibirsk, Russia, 178 p.

, V. D. Gulyaev, and V. L. Kontrimavichus. 2011. A redescription of Arostrilepis horrida (Linstow, 1901) and descriptions of two new species from Palearctic microtine rodents, Arostrilepis macrocirrosa sp. n. and Arostrilepis tenuicirrosa sp. n. (Cestoda: Hymenolepididae). Folia Parasitologica 58: 108-120.

- And V. L. Kontrimavichus. 2011. A redescription of Arostrilepis beringiensis (Kontrimavichus et Smirnova, 1991) and descriptions of two new species from Palearctic microtine rodents, Arostrilepis intermedia sp. n. and A. janickii sp. n. (Cyclophyllidea: Hymenolepididae). Folia Parasitologica 58: 289-301.

Mas-Coma, S., and F. Tenora. 1997. Proposal of Arostrilepis n. gen. (Cestoda: Hymenolepidae). Research and Reviews in Parasitology 57: 93-101.

Musser, G. G., and M. D. Carleton. 2005. Superfamily Muroidea. In Mammal species of the world: A taxonomic and geographic reference, 3rd ed., D. E. Wilson and D. M. Reeder (eds.). Johns Hopkins University Press, Baltimore, Maryland, p. 894-1522.

Rausch, R. L. 1952. Studies on the helminth fauna of Alaska. XI. Helminth parasites of microtine rodents-Taxonomic considerations. Journal of Parasitology 38: 415-444.

. 1957. Distribution and specificity of helminths in microtine rodents: Evolutionary implications. Evolution 11: 361-368.

Ryzhikov, K. M., E. V. Gvozdev, M. M. Tokobaev, L. S. Shaldybin, G. V. Matzaberidze, I. V. Merkusheva, E. V. Nadtochil, I. G. Khohlova, and L. D. Sharpilo. 1978. Keys to the helminths of the rodent fauna of the USSR. Cestodes and trematodes. Izdatel'stvo Nauka, Moskva, Russia, $232 \mathrm{p}$

SCHILLER, E. L. 1952. Studies on the helminth fauna of Alaska. X Morphological variation in Hymenolepis horrida (von Linstow, 1901) (Cestoda: Hymenolepididae). Journal of Parasitology 38: 554-568.

Spassky, A. A. 1954. Classification of hymenolepidids of mammals. Trudy Gel'mintologcheskoy Laboratorii 7: 120-134.

Voge, M. 1952. Variation in some unarmed Hymenolepididae (Cestoda) from rodents. In University of California Publications in Zoology, Vol. 57, H. Kirby, R. M. Eakin, A. Miller, and C. Stern (eds.). University of California Press, Berkeley, California, p. 1-52. 